\begin{tabular}{c} 
Volume and Issues Obtainable at Center for Sustainability Research and Consultancy \\
Sustainable Business and Society in Emerging Economies \\
ISSN: $2708-2172$ \& (E): $2708-2504$ \\
Volume 3: Issue 1 March 2021 \\
CSRE \\
Journal homepage: $\underline{\text { www.publishing.globalcsrc.org/sbsee }}$ \\
\hline
\end{tabular}

\title{
The Effect of Leverage and Debt Maturity on the Corporate Financial Performance: Evidence from Non Financial Firms Listed at Pakistan Stock Exchange
}

*Naveed Khan, Islamia College University, Peshawar, Pakistan

Hamid Ullah, Faculty of Management Sciences, Islamia College University, Peshawar, Pakistan

Mustafa Afeef, Faculty of Management Sciences, Islamia College University, Peshawar, Pakistan

*Corresponding author's email address: mandoori42@gmail.com

ARTICLE DETAILS
History
Revised format: Feb 2021
Available Online: Mar 2021

Keywords

Return on Assets, Return on Equity, Short-term Leverage, Long-term Leverage, Size.

JEL Classification

$M 1, M 12$

\begin{abstract}
Purpose This study examined the effect of leverage, debt maturity on corporate financial performance of non-financial firms listed at the Pakistan Stock Exchange. Targeted population of this study was 100 firm listed at PSX as KSE-100 index out of which 74 non-financial firms were selected from 28 different sectors for the period of 5 years 2013 to 2017.
\end{abstract}

Design/Methodology/Approach: Financial performance measured by ROA, ROE, while leverage, short term leverage, long term leverage taken as independent variables, four variables were taken as control which are size, current ratio, sale growth, tangibility. On the basis of Hausman test, results of random effect model were found appropriate.

Findings: ST and LT Leverage have a negative significant and insignificant effect on financial performance (ROA) respectively, moreover long term leverage has a positive and significant but short has a negative and insignificant effect on ROE. The results of the control variables showed that size has a negative and significant effect on ROA and ROE, whereas current ratio has insignificant and negative effect on ROA, ROE. Sale growth has a positive and insignificant effect on firms ROA and ROE. Tangibility has insignificant and negative effect on financial performance.

Implications/Originality/Value: This study is consistent with traditional trade-off theory and recommended that management of the non-financial firms listed at the PSX should employ minimal debt level or use an optimal level of capital structure and also to attract good management thus to improve their financial performance.

(C) 2021 The authors, under a Creative Commons AttributionNonCommercial- 4.0

\footnotetext{
Recommended citation: Khan, N., Ullah, H. \& Afeef, M. (2021). The Effect of Leverage and Debt Maturity on the Corporate Financial Performance: Evidence from Non Financial Firms Listed at Pakistan Stock Exchange. Sustainable Business and Society in Emerging Economies, 3 (1), 35-47.
}

\section{Introduction}

In today competitive business environment, there is a race is an every aspect of firm activities, the specters is even in liquidity term or in performance term both cling a wings towards survival of firms in 
the market, as concern leverage also plays an important roles in today competitive worlds, there is a wide context writing on corporate finance, which broadly accepted, leverage and maturity formation are essential aspects especially in term of addressing manager and shareholder conflict which we called an agency problem in today septic corporations.

However, Miller and Modigliani, (1958) suggests that in a pretentious Market, the value of firms is not only relevant to capital structure. Moreover, there is a reality of market imperfections (usually when there is asymmetric information, taxes, and conflict of interest) and these subtle formulate CS preference pertinent to the company worth. (Modigliani \& Miller, 1963; Jensen \& Meckling, 1976; Myers, 1977; Myers \& Majluf, 1984). Surprisingly, Modigliani and Miller, (1963), argued that the value of firms and COC is widely effect by the corporation taxes. However, when there is an absence of taxes regulation, the governance mechanism of debt capital can affect financial performance of corporation. (Jensen \& Meckling, 1976).

When there is a clash between company representative and company owner and debt holders we usually term it an agency problem, ultimately effects and raise an intention of agency cost for a firm and for the corporation financial system (Alchian \& Demsetz, 1972; Jensen \& Meckling, 1976). On the argument of Jensen and Meckling (1976), the agency problem (cost of equity) is arises when there is a conflict or even mismanagement of daily activities between manager and shareholders, usually when the company ownership control is separated.

As stated the above situation, the manager make himself as self-dependent and tires to indulge himself in overstated activities which are not come under the arena of his core responsibility (salaries, perks). And sometimes tries to manipulate the basic compensation and reputation of firms at sake of shareholder wealth, rather than maximizing firm and shareholders' value. However, leverage mechanism is most prominent financial instrument which can mitigate agency COE. (Jensen \& Meckling, 1976; Fama \& Jensen, 1983; Jensen, 1986; Stulz, 1990; Jensen, 1993).

For insistence, Jensen (1986), Concluded, the most persistent and valuable den amour for firm valuation is the expected larger cash flow and intrinsic opportunistic opportunity which in term commits prime intense of premium payment to debt holders, as compared to equity ratio, a higher debt ratio meanwhile decrease the agency problem and thus increase a firm financial performance by insisting manager to align the core interest with shareholder's interest. Uncovered loops holes of capital structure studies imbedded the association of maturity of debt and financial, investment decision, and as on firm performance indicators. Most studies argued that short term maturity in detail situation accelerates and efficient CG mechanism to alleviate and agency cost and cost of COE. Although Myers (1977), culminate that the post prominent components of financial instrument is short-term debt with curtail the conflict between shareholders and bondholders and decline the risk of underinvestment strategy problem.

On the other hand, Schiantarelli and Jaramillo (1996) based his argument which is for efficient and improvement of firm productivity is long-term debts which helps the company representative and access better and improvable technology, which in term provide reluctances to firm through which they can finance their operation due to high level of liquidity risk. Although Tian and Estrin (2007); Firth et al. (2008) and Vijayakumaran (2019), examined the upshot of debt and maturity financing and its reflection of agency cost which is faced by the Chinese listed firms, their study aimlessly finds that government's ownership of bank and firms, and soft budget constraints make and an invaluable and inefficient mechanism of governance which is helping in reduction of agency cost for listed firms of china and particularly SOEs.

According to Nyamita (2014), financing decision for corporation is very vital. Instead of equity financing debt financing have pretentious influence on corporate financial system to its alleged 
operation. Accord from that debt financing can also lead to superior performance albeit it is harmful as well in shape of failure for corporation. Financial manager need to be efficient and curious in making finical obligation. With the usage of leverage corporation can earn fixed payment on funds. Abubakar (2015), outlook the same context and state that financial leverage avails the opportunity to the debt holder to get the fixed amount of return, albeit it can be risky to if the project become worthless, then they are entitled to higher loss, on principal amount the premium or interest is required to paid. Nawaiseh (2015) argued the context and state that, for survival of firm and for its continuity usually liquidity and profitability are important determinant, albeit profitability can also be influenced by financial leverage, sometimes in under-investment policy which is making by financial manager which interim liquidity makes challenges.

Moreover, a series of study which had been conducted on this topic brings a notion with constant reforms which assigned that, debt financing as compeered to equity financing and an effective governance mechanism which can reduce agency costs. Accord from above existing literature an extensive study had been done on this research area in context of Pakistan. However, this study will fill the gap of literature on leverage, debt maturity and its effect on FP of Non-financial firms listed at Pakistan Stock Exchange.

The prime motive of this revision is to critically underpin the effect and association between leverage, debt maturity and it upshot on CPL by taking the non-financial firms listed on PSX as KSE-100 index, while for the time of 2013-2017.

This revision will make many contributions to the existing literature. In the first attempt, it will provide supporting evidence from Pakistan's listed non-financial companies, provide concluding comments on leverage and its impact on the company's financial performance, as well as later debt maturity and its impact on the company's financial performance. Cai et al., (2008) tested this research by studying Chinese listed companies. They stated that they found no supporting evidence between leverage, debt maturity and their impact on the company's financial performance. In the context of Pakistan, various studies have been conducted in this area, but this revision will add debt maturity and other control variables to check its results on the CFL.

\section{Review of Related Literature}

In the prior content, the supportive hypothesis and related literature review of debt maturity, leverage and its effect on corporate performance are discussed.

\section{Leverage and Firm Performance}

According to the concepts and details of an agency theory it augmented that control of firms and separation of ownership leads the clash between agent and potential principal of company (Berle \& Means, 1932; Jensen \& Meckling, 1976). For occasion, the company's representative some time discord the potential interest, even desired and up lit the prior and perquisites consumption, and invent in un sound petty projects which is have no existing concerns with shareholder's wealth maximization. Concurringly, further the theories also suggest that the best tools to alleviate the agency cost of outside (equity) are leverage. In finance arena debt finance is a mechanism which controls the following flows of business: (1) the company representative (Manager) is closely monitored by the debt holders and financial markets (Jensen and Meckling, 1976; Fama and Jensen, 1983). (2) The debt holders always have the right of fixed payment in shape of interest which in turn reduces the exceeding and planning free cash flows which the company managements acquired for discretionary spending (Jensen, 1986). (3) Consistently zwiebel, (1996) suggests that for company executive's debt is serving as fixed and commitment device.

For the sake of interest the legal obligation of companies executive is to make interests payment to debt holders, for instance when they fail to meets this obligation there is prior chance of risk and liquidation 
of business which ultimate in turn may influence the reputation and growth opportunities (Fama,1980; Grossman \& Hart, 1982; Williams, 1987). This stunt limits company manager with an increment to work in their domain and consume fewer perks as compared to higher (Grossman \& Hart, 1982; Zwiebel, 1996).

For instance, Aghion and Bolton (1992) and Gilson (1990) suggests that financial cuts up or turmoil or when there is decreasing low profit trend, it may lead to a control curve of firm to the debt holders, with in turn may create a marks for incumbent manager. In curtail, these remarks argue with pin that higher debt ratio decrease the organization cost rather than equity financing, by aligns the interests of company owner and company representative, and in turn it will have a constructive contact on CPL.

However, the excess of using debt financing instead of equity financing, the agency COE is not mere costless. The up leading formation of capital debt in any firms leads to the conflict of interest between shareholder and debt holders which creates an agency cost of debt,

When there is higher usage of debt financing, company agent who work on behalf of company owner's some times for go an excessive and fruitful projects which have a positive NPV, because of risky debts which absorbs a segmented parts of company owner benefits. Although Myers (1977), argue that the persistent usage of under-investment policy and its related problems of higher leverage level. Up sum and excessive use of FL also increase the agency costs. This is priory link with risk liquidity and bankruptcy cost of any company

These moral peril harms indicate that excessive use FL may unconstructively influence corporate financial performance. Some previous observed result on the association between FL and corporate financial performances are mixed. Although Dessí and Robertson, (2003), in the literature light they argued that in observed and unobserved firm's debt is endogenously determine which is consistent and prior with firms worth sum up. Others Majumdar and Chhibber (1999) concluded unconstructive association between FL and CFP. By distinguish, Berger and Di Patti (2006) culminates that after controlling endogeneity there is constructive connection between FL and CFP.

Although Weill (2008), argued that the connection and link flanked by FL and CFP is varying across countries, while the association involve in these two is constructive in five countries, Belgium, France, German, Norway and Spain, and in turn it is negatively Italy and not even significant in Portugal, it further suggests that some organizational aspect may affect this association. Moreover, Sarkar and Sarkar (2008), finds that usage of debt financing instead of equity financing is helpful authority system of listed Indian companies with consistent upgrading in organizational surroundings which has become promote leaning. With prior concern, in Chinese context, previous and latent revise suggests that FI and company are worked under the domain of concern Chinese government; FL is fruitless source to alleviate organization conflict especially of State Owned enterprises. (Tian \& Estrin, 2007; Firth et al., 2008).

Conquerors (usually government-owned banks) are no longer the same as demonstrating the behavior of managers and shareholders, and the organization will not be retained. In addition, current research trends show that the chain transformation of the banking system and governance mechanism of listed companies in China, rather than equity financing, debt financing is an effective tool to reduce agency costs (Cull and Xu, 2005; Ayyagari et al., 2008; Firth et al. People, 2009; Vijayakumaran, 2017; 2019). Although Raza (2013) revised the impact of FL on FP, they used panel data of companies listed on PSX from 2004 to 2009 to prove their results. They believe that financial leverage has an unconstructive effect on cash flow, and he concluded that the use of high levels of debt will lead to a decline in company performance.

In addition, Syed et al. (2015) used panel data from 1999 to 2012 to study the impact of financial leverage on the company's financial performance, and demonstrated their supporting evidence by 
sampling the textile industry. Their research finally concluded that financial Leverage has no constructive effect on company performance as measured by ROA, Tobin Q. The main reason for this negative trend is to borrow large amounts of interest from banks to pay interest, rather than the inefficient capital market assumptions. Conqueringly Banafa, Muturi, and Ngugi (2015) investigated the impact of financial leverage on company performance by demonstrating their results on selected nonfinancial companies in Kenya between 2009 and 2013. They believe that FL has a non-constructive effect on CFP.

H1: Financial leverage has significant effect on the corporate financial performance.

\section{Debt Maturity and Firm Performance}

Literature on $\mathrm{CF}$ marked that enticement characteristic of short term debt maturity make it more interesting, valuable, controlling and efficient than LTD maturity in alleviating an agency clash between company agent and shareholders. Concurringly, Myers (1977) suggests that the best optimum tools which mitigates the clash between bond holders and equity owner is short term debt and its growth exercise option of investment policy. Companies who use greater growth option visage superior investment problems.

Furthermore, Myers (1997) finds that, firms whose growth option is at peaked are likely to employ short term debt maturity. Debt which becomes mature before its execution of an investment option, in turn it cannot lead to suboptimal investment decisions. Further it up sum that in underinvestment policy it deteriorates profit in long run, such amplification order and navigates unconstructive association between long term debts and financial performance. Moreover, Leland and Toft (1996) argued that short term debt is the prior tools which can reduce the agency costs in term which is associated with the shareholder's risk shifting behavior. Consistently from long term maturity short term maturity is more effective in imposing a pressure on manager to refinance and reassign the rights from holder to creditors, (e.g., Diamond, 1991; Hart and Moore, 1994;1998; Rajan and Zingales, 1995; Stulz, 2000).

Hart and Moore (1995), in financing arena short term debts maturity improve the latent flexibility to the manager for optimum use of assets in accord with their subscribe goals and empire building. To preventive the capability of manager to build and empire by funding new and fruitful project base on assets allocation is long term debt financing. Baum et al., (2007) reports that STD is optimistically effects corporate performance of German listed firms (a bank-based economy). Similarly, Abor (2005) reported short term debt maturity has constructive effect on corporate performance. In contrary stance, Schiantarelli and Jaramillo (1996); Schiantarelli and Sembenelli (1997) and Schantarelli and Srivastava (1996), suggests their observed facts, short term debt is not the only tools which can improve firm performance when calculated by total factor productivity. The short term debt is popular in Chinese firm, because $86 \%$ of short term debts are mature within one year.

Chinese banks tires to curtail their superior revelation of company associated and explicit menace, which is in turn, raise market orientation in shape of loan strategy, by curbing debt maturity structure. This loan strategy affects unconstructively corporate financial performance (Huyghebaert \& Wang, 2016). Accord from its debt maturity is more comprehensible tools which improves firm productivity, because it enhances an opportunity for firms to access and to provide productive technology, in turn the firms might go to funding with debt because of its high level liquidity risk (Schiantarelli \& Jaramillo,1996).

H2: There is a significant effect of debt maturity on corporate financial performance.

\section{Theoretical Under Pinning}

According to Trade-off theory the company must ensure level of leverage through optimum level of capital structure which maximize and enhanced their worth, ultimately in term it also benefit the company in point of tax shield benefits against financial distress cost by using debt financing. Surprisingly the paradigm of this theory also forecast that, there is an incentive for firm through which 
they can move towards leverage ratio by latent sort of any other deviations. (Frank \& Goyal, 2008). Fischer et al., (1989) postulate that using an optimum level of debt and equity financing by any company sometimes face considerable resistance towards prior adjustment of cost which is associated with debt financing.

\section{Conceptual Frame Work}

The following figure 1.2 shows the conceptual frame work of the study.

\section{Independent Variables \\ Leverage and Debt Maturity}

Dependent Variables Firm Performance

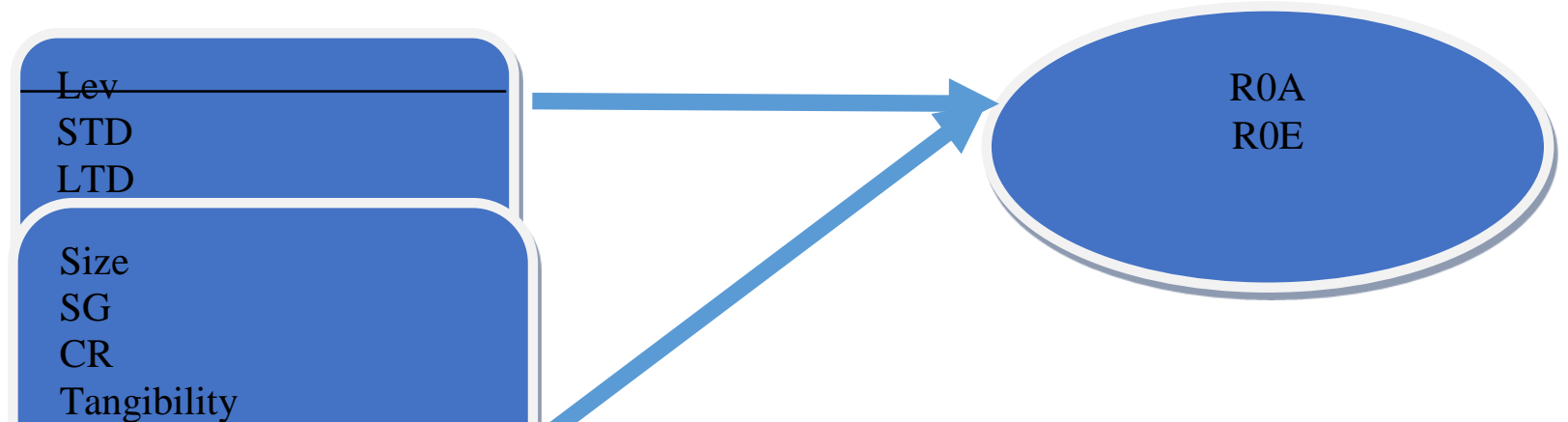

Figure 2.1

\section{Research Methodology}

Panel data type is used in this revision, and data is secondary in nature and sources of the data are taken from annual FSA reports published by State bank of Pakistan and company investor information report. While time frame of this study is from 2013-2017. Moreover, sample selection of this study were composed of listed companies at Pakistan Stock Exchange non-financial sectors, while financial sectors were excluded due to the influence of potential outliers, while 74 companies were selected from 28 different sectors, this study ended up with a panel observation of 370, and these companies has selected on the basis of data availability.

\section{Variables Measurements}

The following content explain the contextual definition and previous existing literature finding.

\section{Performance Measures}

The following Baum et al. (2007) and approaches were used to measure R0A and R0E. While R0A is define as earnings before interest and taxes divided by year-end TA.

Return on Equity (R0E) was measured by Earning's after taxes divided by total Shareholder's equity.

\section{Explanatory Variables}

The explanatory variable is the ratio of total Lev and STD in total debt, which is used to capture the impact of CS decision on CPF. Following Dessiand Robertson (2003) and Margaritis and Psillaki (2010), leverage is defined as the ratio of total debt to total assets. As described by Schiantarelli and Sembenelli (1997) and Baum et al. (2007), this study uses the ratio of short-term debt to total debt (short-term debt divided by total debt) as a proxy for debt maturity.

\section{Size of Firm}

Accord with the previous revision Size of firm essential determinant for any CPF and previous revision suggest a constructive connection between Size and FP. With an increase in Firm Size it ultimate have sound effect on firm, like larger firms are always expected to have bigger share size, have equipped technology and to be more managerial transparency with associated risks than smaller firms. 
(Himmelberg et al., 1999; Greenaway et al., 2007; Dixon et al., 2017).

\section{Tangibility}

Himmelberg et al. (1999) Suggest that for debt collateral tangibility can be used as monitor, which can alleviate and organization clash between owner and company's management. An inverse association observed between tangibility and financial performance when there is in efficiency utilization of tangible assets. If a firm used it efficiently, there is expected to be positive association between these two determinates.

\section{Sales Growth}

Majumdar and Chhibber (1999), SG has impression to show the business cycle effect which is aligned with environment volatility. Like Firm Size, SG also represents company growth. With this scenario's the SG can indicates company able to assume expected earnings. Accord with preceding context there is expected constructive association between SG and financial performance. This study expects and observe a constructive alliance between SG and PF.

\section{Liquidity}

Like an SG, in this revision Liquidity used as moderator variable which is measured by Current Ratio, like it has characteristics to capture corporate manager ability in term efficient utilization of current assets and current liability. The efficient utilization of CR has direct effect on firm performance.

\section{Variables of the Study}

This study has used the following variables

Table

\begin{tabular}{|c|c|c|c|}
\hline Variables & Anonyms & Measurements & Approach Used \\
\hline \multicolumn{4}{|l|}{ Exploratory Variables } \\
\hline \multicolumn{4}{|l|}{ Performance } \\
\hline Return on Assets & ROA & $\begin{array}{l}\text { EBITD/ year-end total } \\
\text { assets. }\end{array}$ & Baum et al.(2007) \\
\hline Return on Equity & ROE & $\begin{array}{l}\text { Net profit/Total } \\
\text { shareholder's equity }\end{array}$ & \\
\hline \multicolumn{4}{|l|}{ Independent Variables } \\
\hline Leverage & LEV & Total leverage/ total assets & $\begin{array}{l}\text { Dessi and Roberston } \\
(2003)\end{array}$ \\
\hline ST- Debt & PROP_STLEV & $\begin{array}{l}\text { Short-term liabilities/ total } \\
\text { liabilities }\end{array}$ & $\begin{array}{l}\text { Margaritis and Psillaki } \\
(2010)\end{array}$ \\
\hline Long-term debt & PROP_LTLEV & $\begin{array}{l}\text { Long-term liabilities/ total } \\
\text { liabilities }\end{array}$ & $\begin{array}{l}\text { Schiantarelli } \\
\text { Sembenelli (1997) }\end{array}$ \\
\hline \multicolumn{4}{|l|}{ Control Variables } \\
\hline Size & Size & $\begin{array}{l}\text { Natural logarithm of total } \\
\text { real asset }\end{array}$ & $\begin{array}{l}\text { Log of total assets Scott } \\
\text { and Martin (1975) }\end{array}$ \\
\hline SALGRTH & SG & $\begin{array}{l}\text { Changès in salès /Total } \\
\text { rèal salès } t-1\end{array}$ & \\
\hline Tangibility & TANG & Fixed assets/ Total Assèts & \\
\hline Liquidity(Current Ratio) & LIQ, CR & $\begin{array}{l}\text { Current Assets/ Current } \\
\text { Liability }\end{array}$ & \\
\hline
\end{tabular}

\section{Model Estimation}

Regression is used to predict the values of quantitative outcome of exploratory variable using several other predicative variables. Multiple regressions analysis shows the communal upshot of independent variables on the dependent variable.

$\mathrm{ROA}_{i \mathrm{t}}=\alpha \mathrm{o}+\beta 1 \mathrm{LEV}_{\mathrm{it}}+\beta 2$ Prop_short Levit $+\beta 3$ Prop_long Levit $_{\text {it }}+\beta 4 \mathrm{Size}_{\mathrm{it}}+\beta 5 \mathrm{Tang}_{\mathrm{it}}+\beta 5 \mathrm{SGrowth}_{\mathrm{it}}+\beta 6$ $\mathrm{CR}_{\mathrm{it}}+€_{\mathrm{it}}$ 
$\mathrm{ROE}_{\mathrm{it}}=\alpha \mathrm{o}+\beta 1 \mathrm{LEV}_{\mathrm{it}}+\beta 2$ Prop_short Levit $+\beta 3$ Prop_long Levit $+\beta 4 \mathrm{Size}_{\mathrm{it}}+\beta 5 \mathrm{Tang}_{\mathrm{it}}+\beta 5 \mathrm{SGrowth}_{\mathrm{it}}+\beta 6$ $\mathrm{CR}_{\mathrm{it}}+€_{\mathrm{it}}$

Whereas in the following equation 1,2 where $\mathrm{i}$ represent indexes firms and $\mathrm{t}$, years of all variables including dependent, independent, controls variables, finally $€_{i t}, I$ represent firm specific error term with time $\mathrm{t}$ trend.

\section{Results and Discussion}

This section includes results and discussions on the results of the different tests applied such as descriptive statistics, correlation and regression.

\section{Descriptive Statistics}

\begin{tabular}{lrrrrr}
\hline Variable & Obs & Mean & Std.Dev. & Min & Max \\
\hline ROA & 370 & .175 & .168 & -.437 & 1.302 \\
ROE & 370 & .283 & .434 & -1.585 & 4.139 \\
LEV & 370 & .536 & .217 & -.484 & 1.2 \\
ST LEV & 370 & .128 & .183 & -.218 & .945 \\
LT LEV & 370 & .12 & .181 & -.349 & 1.82 \\
SIZE & 370 & 7.515 & .466 & 6.139 & 8.797 \\
SG & 370 & -.054 & 3.564 & -68.204 & 1.303 \\
CR & 370 & $1.623 ;$ & .961 & .129 & 6.388 \\
TANG & 370 & .556 & .366 & .001 & 1.94 \\
& & & & & \\
\hline
\end{tabular}

Table 4.1 illustrates the statistical summary of the data. The average ROA ratio of non-financial companies is 0.175 , and the minimum and maximum ROA are -.437 and 1.302. In addition, the average value of ROE is 0.283 , while 4.139 and -1.585 is maximum and minimum value. The results show that the average value of leverage is 0.536 , the minimum and maximum values are -.484 and 1.2 respectively, while the average value of short-term leverage is 0.128 , and its minimum and maximum values are -.218 and 0.945 , respectively. Financial companies use low debt, while others use very high debt ratios to finance themselves. The results also show that the average size value expressed in natural logarithm is 7.515 , the maximum value is 8.797 , and the minimum value is 6.139 . Current ratio has mean value of 1.62 which shows the average payment of current liability which is cover by current assets of sample firms, while CR has maximum value of 6.388 and its minimum value is.129 which shows the trend while the standard deviation shows the fluctuation of data, while sales growth of selected sample which is calculated by annual sales growth shows a negative trend and decline of $-5 \%$. While the average mean value of tangibility is .566 and it has utmost value of 1.94 and least values of .001 respectively.

\section{Matrix of Correlations}

\begin{tabular}{|c|c|c|c|c|c|c|c|c|c|}
\hline Variables & (1) & (2) & (3) & (4) & $(5)$ & (6) & (7) & (8) & $(G$ \\
\hline (1) ROA & 1.000 & & & & & & & & \\
\hline (2) ROE & 0.468 & 1.000 & & & & & & & \\
\hline (3) LEV & -0.352 & 0.063 & 1.000 & & & & & & \\
\hline (4) ST LEV & -0.405 & -0.234 & 0.220 & 1.000 & & & & & \\
\hline (5) LT LEV & -0.251 & -0.072 & 0.147 & 0.180 & 1.000 & & & & \\
\hline (6) SIZE & -0.272 & -0.099 & 0.214 & 0.064 & 0.114 & 1.000 & & & \\
\hline (7) SG & 0.065 & 0.072 & -0.064 & -0.001 & 0.027 & -0.025 & 1.000 & & \\
\hline (8) CR & 0.286 & -0.011 & -0.745 & -0.258 & -0.248 & -0.104 & 0.036 & 1.000 & \\
\hline (9) TANG & -0.237 & -0.131 & -0.041 & 0.019 & 0.312 & 0.025 & 0.015 & -0.171 & 1.000 \\
\hline
\end{tabular}

Table 4.2 reports the correlation matrix between the variables. Lev and R0A are negatively correlated. It is positively correlated with R0E. The LTD ratio was significantly negatively correlated with R0A, negatively correlated with R0E, and STD ratio was negatively correlated with ROA. Because it has a 
significant negative correlation with R0E. Turning to control variables, as expected, SG is significantly positively correlated with R0A and R0E, and the current ratio is positively correlated with R0A. CR and R0E are significantly negatively correlated. Although tangibility is not significantly negatively correlated with R0A, it is negatively correlated with R0E. Finally, it is interesting that company size is negatively correlated with R0A but not statistically significant, while size and company performance

\begin{tabular}{|c|c|c|c|c|c|c|}
\hline \multirow{2}{*}{$\begin{array}{l}\text { Variable } \\
\text { Name }\end{array}$} & \multicolumn{3}{|c|}{ Result of Fixed Effect Model } & \multicolumn{3}{|c|}{ Result of Random Effect Model } \\
\hline & Co-efficient & T-value & P-value & Co-efficient & T-value & P-value \\
\hline LEV & -0.271 & -5.05 & $0.000 * * *$ & -0.262 & -5.47 & $0.000 * * *$ \\
\hline ST LEV & -0.065 & -1.22 & 0.225 & -0.153 & -3.38 & $0.001 * * *$ \\
\hline LT LEV & -0.019 & -0.50 & 0.619 & -0.048 & -1.35 & 0.176 \\
\hline SIZE & -0.135 & -3.02 & $0.003 * * *$ & -0.094 & -3.75 & $0.000 * * *$ \\
\hline SG & 0.001 & 0.80 & 0.426 & 0.001 & 0.84 & 0.400 \\
\hline $\mathbf{C R}$ & -0.007 & -0.58 & 0.563 & -0.013 & -1.22 & 0.222 \\
\hline Tang & -0.052 & -0.95 & 0.342 & -0.080 & -2.52 & $0.012 * *$ \\
\hline Constant & 1.386 & 3.96 & $0.000 * * *$ & 1.108 & 5.83 & $0.000^{* * *}$ \\
\hline Fitted Model & \multicolumn{5}{|c|}{ Random Effect Model } & \\
\hline $\begin{array}{l}\text { Hausman } \\
\text { Test } \\
\text { (P-value) }\end{array}$ & $\begin{array}{l}\text { Chi-square } \\
\text { P-value }\end{array}$ & value & $\begin{array}{r}\text { est } \\
\text { Coef. } \\
11.306 \\
.126 \\
\end{array}$ & & & \\
\hline Observation & \multicolumn{3}{|c|}{370} & \multicolumn{3}{|c|}{370} \\
\hline R-square & \multicolumn{3}{|c|}{$17.3 \%$} & \multicolumn{3}{|c|}{$30.5 \%$} \\
\hline
\end{tabular}

measured by R0E are statistically negatively correlated. Finally, the table below shows the Collinearity between the explanatory variables of the model that passed the VIF test.

Table

Variance inflation Factor

\begin{tabular}{lrr}
\multicolumn{3}{c}{ Variance inflation Factor } \\
\hline CR & VIF & 1/VIF \\
LEV & 2.582 & .387 \\
TANG & 2.526 & .396 \\
LT LEV & 1.199 & .834 \\
ST LE & 1.191 & .839 \\
SIZE & 1.095 & .914 \\
SG & 1.07 & .935 \\
Mean VIF & 1.006 & .994 \\
\hline
\end{tabular}

Table Relationship of Independent Variables with ROA. 


\begin{tabular}{|l|c|}
\hline $\begin{array}{l}\text { F-test value } \\
\text { (P-value) }\end{array}$ & $\mathbf{8 . 5 7 0}$ \\
\hline
\end{tabular}

Table4.4 indicates that that Lev has significant negative relationship with FL measured by ROA, as indicated by the beta vale of $(-0.262)$ significance value of $(0.000<0.05)$. This means that a unit increase

\begin{tabular}{|c|c|c|c|c|c|c|}
\hline $\begin{array}{l}\text { Variable } \\
\text { Name }\end{array}$ & \multicolumn{3}{|l|}{ Result of Fixed Effect Model } & \multicolumn{2}{l|}{ Result of Random Effect Model } \\
\hline & Co-efficient & T-value & P-value & Co-efficient & T-value & P-value \\
\hline Leverage & 0.813 & 3.38 & $0.001^{* * *}$ & 0.445 & 2.48 & $0.013^{* *}$ \\
\hline Shortlev & -0.434 & -1.82 & $0.070^{*}$ & -0.574 & -3.67 & $0.000^{* * *}$ \\
\hline Longlev & 0.067 & 0.39 & 0.694 & 0.033 & 0.23 & 0.814 \\
\hline Size & 0.087 & 0.43 & 0.665 & -0.119 & -1.71 & $0.087^{*}$ \\
\hline SG & 0.008 & 1.53 & 0.128 & 0.009 & 1.67 & $0.095^{*}$ \\
\hline CR & 0.020 & 0.38 & 0.703 & 0.019 & 0.47 & 0.637 \\
\hline Tang & 0.576 & 2.36 & $0.019^{* *}$ & -0.077 & -0.85 & 0.397 \\
\hline Constant & -1.110 & -0.71 & 0.480 & 1.019 & 1.95 & $0.052^{*}$ \\
\hline Fitted Model & \multicolumn{7}{|l|}{ Random effect Model } \\
\hline $\begin{array}{l}\text { Hausman } \\
\text { Test }\end{array}$ & \multicolumn{7}{|l|}{ Coef. } \\
\hline
\end{tabular}

in financial leverage reduces FP by 0.26 units' financial leverage has an adverse effect on FP of nonfinancial firms listed at the PSX. Short term leverage has co-efficient of -0.153 and individual $t$ statistics has a value of -3.38 which means that short term leverage has negative and significant effect on firm FP measured by ROA, meanwhile long term leverage has coefficient $0 \mathrm{f}-0.048$ and individual $\mathrm{t}$ statistics value is -1.35 which means that LT leverage negative and insignificantly effect FP, as turning to control variables Size has a coefficient of- 0.094 and individual $t$ statistics value is -3.75 which means that Size has negative but significant effect on firm FP on selected sample, which portrays that a unit change in firm Size $0.09 \%$ decrease will occur in selected non-financial firms. Sales growth has positive but insignificant effect on firm financial performance, meanwhile if we look at the Current ratio it has co efficient of -0.013 and individual $t$ statistics has value of -1.22 which means that $C R$ has negative and insignificant effect on performance on selected sample, which means that a unit increase in CR will bring $0.07 \%$ decrease in ROA. Tangibility has coefficient of -0.080 and individual $t$ statistics has value of -2.52 which means that tangibility has negative and significant effect on firm FP, one unit change in fixed assets to total assets will cause $0.052 \%$ change in ROA. Moreover, this revision has explanatory power of $30.5 \%$ which means that ROA is that much explained by independent and control variables in selected non-financial firm, moreover overall model is statistically significant on the basis of F-test value and on the recommendation of Hausman test P-value (.126>0.05) REM is fitted for this study. 


\begin{tabular}{|l|cr|c|}
\hline \multirow{2}{*}{ Observation } & $\begin{array}{l}\text { Chi-square test value } \\
\text { P-value }\end{array}$ & \multicolumn{3}{|c|}{$\begin{array}{r}12.184 \\
.095\end{array}$} \\
\hline R-square & $\mathbf{3 7 0}$ & $\mathbf{3 7 0}$ \\
\hline $\begin{array}{l}\text { F-test value } \\
\text { (P-value) }\end{array}$ & $\mathbf{7 \%}$ & $\mathbf{3 . 0 5 5}$ & $\mathbf{1 3 \%}$ \\
\hline
\end{tabular}

Table Relationship of Independent Variables with ROE.

Table 4.5 indicates that that Lev has significant positive relationship with FP measured by ROE, indicated by the beta vale of 0.445 significance value of $(0.013<0.05)$. This means that a unit decreases in financial leverage will increase FP, ROE by $0.44 \%$ financial leverage has direct effect on FP measured by R0E of non-financial firms listed at the PSX. Short term leverage has co-efficient of -0.574 and individual $t$ statistics has a value of -3.67 which means that short term leverage has negative and significant effect on firm FP measured by ROE, meanwhile long term leverage has coefficient 0 f 0.033 and individual $t$ statistics value is 0.23 which means that long term leverage has positive and insignificant effect on FP measured by ROE, as turning to control variables Size has a coefficient of0.119 and individual $t$ statistics value is -1.71 which means that Size has negative but insignificant effect on firm FP on selected sample, which portrays that a unit change in firm Size $11.9 \%$ decrease will occur in selected non-financial firms. Sales growth has positive but insignificant effect on firm financial performance, meanwhile if we look at the Current ratio it has co efficient of 0.019 and individual $t$ statistics has value of 0.47 which means that $C R$ has positive and insignificant effect on performance on selected sample, which means that a unit decrease in CR will bring $0.019 \%$ increase in ROE. Tangibility has coefficient of -0.077 and individual $t$ statistics has value of -0.85 which means that tangibility has negative and insignificant effect on firm FP, one unit change in FA to TA will cause $0.077 \%$ change in ROE.

Moreover, this revision has explanatory power of $13 \%$ which means that ROE is that much explained by independent and control variables in selected non-financial firm, moreover overall model is statistically significant on the basis of F-test value and on the recommendation of Hausman test P-value (.095>0.05) Random Effect Model is fitted for this revision.

\section{Conclusion}

This study use the panel data observations of Pakistan's listed companies from 2013 to 2017. This study examines the impact of FL debt maturity structure on CF. The performance measurement standards are (R0A), (R0E). The standard for Firms Leverage are total leverage, short-term leverage, and long-term leverage. In addition, the control variables are size, current ratio, sales growth, and tangibility.

Studies have shown that FL has significantly and negatively persuaded the FPs of non-financial companies listed on PSX. This study concluded that financial leverage has an adverse effect on PF, so non-financial companies listed on PSX should use the best debt level to ensure that their PF is maximized. In addition, it has a positive and significant impact on financial performance as measured by ROE, while Size has a negative and insignificant impact on FP. Sales growth has a positive but insignificant impact on financial performance. CR has insignificant but constructive and unconstructive effect on FP; tangibility has significant unconstructive but insignificant and unconstructive effect on corporate financial performance. Based on concluding remarks this study suggests that the company needs to use an optimal capital structure or pro rata to maximized their firm performance. Higher debt ratio can result catalytic increase in R0E by regulating capital structure to lower the debt ratio, enlighten with this revision it also supports the theoretical model which is developed by Scott (1976), he argued that when there is imperfect market, there exist an optimal level of capital structure for firm. The above results are consistent with the previous finding Olayinka and Taiwo (2012), Akbarian (2013), Barakat (2014), Raza (2013), Muturi and Ngugi (2015), they argued that FL had unconstructive and significant effect on CFP. 


\section{Limitation and Direction for Future Research}

This study only obtained complete data of 74 non-financial companies from the target population of KSE -100 listed companies. Therefore, the survey results are based on sampled companies and may not be applicable to companies that have not obtained data. In addition, the survey results are based on listed companies. Therefore, we can also take PSX listed financial companies as an example to examine the impact of FL on FP. Therefore, we can further study the impact of operating leverage on the PF of nonfinancial companies listed on the Pakistan Stock Exchange. This study only uses data tables from 2013 to 2017. In addition, although company age and liquidity (a measure of cash and cash equivalents) can also be used as control variables, the study can also be completed by using a larger sample size to check the effect.

\section{References}

Abor, J. (2005). The effect of capital structure on profitability: an empirical analysis of listed firms in Ghana. The Journal of Risk Finance, 6(5), 438-445.

Abubakar, A. (2015). Relationship between financial leverage and financial performance of deposit money banks in Nigeria. International Journal of Economics, Commerce and Management, 3(10), $759-778$.

Aghion, P., \& Bolton, P. (1992). An incomplete contracts approach to financial contracting. The Review of Economic Studies, 59(3), 473-494.

Banafa, A., \& Muturi, W. (2015). The impact of leverage on financial performance of listed nonfinancial firm in Kenya. International Journal of Finance and Accounting, 4(7), 1-20.

Barakat, A. (2014). The impact of financial structure, financial leverage and profitability on industrial companies shares value. Research Journal of Finance and Accounting, 5(1), 55 - 66.

Dessí, R., \& Robertson, D. (2003). Debt, incentives and performance: Evidence from UK panel data. The Economic Journal, 113(490), 903-919.

Fama, E., F. (1980). Agency problems and the theory of the firm. Journal of Political Economy, 88(2), 288-307.

Fama, E.F., \& Jensen, M.C. (1983). Separation of ownership and control. The Journal of Law and Economics, 26(2), 301-325.

Firth, M. C., Lin, P. L, \& Wong, S., M. (2009). Inside the black box, bank credit allocation in Chinese private sector. Journal of Banking \& Finance, 33(6), 1144-1155.

Grossman, S.J., \& Hart, O.D. (1982). Corporate financial structure and managerial incentives. In the economics of information and uncertainty. University of Chicago press. pp. 107-140.

Ijayakumaran, R. (2017). Capital structure decisions and corporate performance: Evidence from Chinese listed industrial firms. International Journal of Accounting and Financial Reporting, 7(2), 562576.

Jensen, M., C. \& Meckling, W.H. (1976). Theory of the firm, managerial behavior, agency costs and ownership structure. Journal of Financial Economics, 3(4), 305-360.

Jensen, M.C. (1986). Agency costs of free cash flow, corporate finance and takeovers. The American Economic Review, 76(2), 323-329.

Jensen, M.C. (1993). The modern industrial revolution exit and the failure of internal control systems. The Journal of Finance, 48(3), 831-880.

Modigliani, F., \& Miller, M.H. (1958). The cost of capital, corporation finance and the theory of investment. The American Economic Review, 48(3), 261-297.

Modigliani, F., \& Miller, M.H. (1963). Corporate income taxes and the cost of capital, a correction. The American Economic Review, 53(3), 433-443.

Mule, M. K., \& Mukras, M.S. (2015). Financial leverage and performance of listed firms in a frontier market, panel evidence from Kenya. European Scientific Journal, 11(7), 547 - 563.

Myers, S.C. (1977). Determinants of corporate borrowing. Journal of Financial Economics, 5(2), 147175.

Myers, S.C., \& Majluf, N.S. (1984). Corporate financing and investment decisions when firms have information that investors do not have. Journal of Financial Economics, 13(2), 187-221. 
Nawaiseh, R.I. (2015). Do profitability and size affect financial leverage of Jordanian industrial listed Companies? European Journal of Business and Innovation Research, 3(5), 1-12.

Nyamita, M.O. (2014). Factors influencing debt financing and its effects on financial performance of state Corporations in Kenya. Doctorate Thesis. Durban University of Technology.

Olayinka, A., \& Taiwo, A. (2012). Profitability and leverage: Evidence from Nigerian Firms. Global Journal of Business Research, 6(1), 17-25.

Raza, M.W. (2013). Effect of financial leverage on firm performance, empirical evidence from Karachi Stock Exchange.

Sarkar, J., \& Sarkar,S. (2008). Debt and corporate governance in emerging economies, evidence from India. Economics of Transition, 16(2), 293-334.

Schiantarelli, F., \& Srivastava, V. (1996). Debt maturity and firm performance, panel study of Indian public limited companies. Policy Research Working Paper Series No. 1724: The World Bank.

Schiantarelli, F., \& Jaramillo, F. (1996). Long-term debt in Ecuador, access and effect on firms' performance. Policy Research Working Paper Series No. 1725: The World Bank.

Schiantarelli, F., \& Sembenelli, A. (1997). The maturity structure of debt, determinants and effects on firm performance? Evidence from the United Kingdom and Italy, Policy Research Working Paper Series No.1699: The World Bank.

Shleifer, A., \& Vishny, R.W. (1997). A survey of corporate governance. The Journal of Finance, 52(2), 737-783.

Tian, L., \& Estrin, S. (2007). Debt financing, soft budget constraints and government ownership, Evidence from China. Economics of Transition, 15(3), 461-481.

Vijayakumaran, R. (2015). Capital structure decisions, agency conflict and corporate performance, evidence from Sri Lankan listed manufacturing companies. International Journal of Accounting and Business Finance, 1(1), 1-14.

Vijayakumaran, R. (2019). Agency costs ownership and internal governance mechanisms, Evidence from Chinese listed companies. Asian Economic and Financial Review, 9(1), 133-154.

Weill, L. (2008). Leverage and corporate performance, does institutional environment matter? Small Business Economics, 30(3), 251-265.

Wintoki, M.B., Linck, J.S., \& Netter, J.M. (2012). Endogeneity and the dynamics of internal corporate governance. Journal of Financial Economics, 105(3), 581-606.

Zwiebel, J. (1996). Dynamic capital structure under managerial entrenchment. The American Economic Review, 86(5), 1197-1215. 